\title{
The Role of Profitability as a Mediating Variable on the Relationship between Loan Deposit Ratio and Stock Return: A Case Study on the Indonesian Stock Exchange
}

\author{
Yusuf Iskandar \\ Sekolah Tinggi Ilmu Ekonomi Jaya Negara Tamansiswa Malang, Indonesia
}

\begin{abstract}
The research is financed by Asian Development Bank. No. 2006-A171(Sponsoring information) Abstract

Stock returns show the financial performance of a banking company. It can be influenced by several factors, such as the loan-to-deposit ratio (LDR) and profitability. This study aimed to determine the effect of LDR on stock returns through profitability as a mediating variable in commercial banks listed on the Indonesia Stock Exchange from 2013 to 2018. There were 20 banks listed on the Indonesia Stock Exchange that met the criteria as a research sample. Data analysis in this study used the SEM-PLS analysis model to test the proposed hypothesis. The results showed that LDR a significant effect on profitability and stock returns, profitability had a substantial impact on stock returns, and, finally, it appeared that profitability could mediate the effect of LDR on stock returns. Based on these findings, the drawn conclusion is that bank companies can better manage liquidity so that profitability and bank stock returns can be maximized.
\end{abstract}

Keywords: Stock Return, Loan-to-deposit Ratio, Profitability, Indonesia Stock Exchange

DOI: $10.7176 /$ RJFA/11-18-15

Publication date:September $30^{\text {th }} 2020$

\section{Introduction}

Financial performance is a picture of a company reflecting its efforts to achieve the success of its activities (Fahmi, 2012). It plays a critical role in evaluating bank operational activities, determining management plans, and analyzing bank activity strategies (Dewi, 2019). It also serves to measure and determine the value or the size of the company by observing the conditions of the business field the company performs, based on its total assets. Besides, financial performance is countable from the level of bank liquidity, such as the volume of credit extended and the number of funds received through various sources. The profit in investing in the capital market can be reflected by the returns on the selected shares. Returns can be in the form of both realized, namely those having occurred, and expected returns, namely those expected to be gained in the future (Jogiyanto, 2008).

The loan-to-deposit ratio (LDR) is a bank's ability to channel the funds it owns, which originated from the public in the form of credit, whose distributable components include savings, time deposits, time deposit certificates, and issued securities (bonds). According to BI regulation number 5/20/P.BI/2003, the use of LDR is set to a maximum of $110 \%$. The amount of credit extended by the bank can determine the bank's profit: when the bank is unable to channel its credit, it can lose money (Kasmir, 2008). The LDR level will affect the level of the company's profitability, with the assumption that the bank must channel credit effectively.

BI Regulation Number 15/7/PBI/2013 concerning LDR states that the minimum statutory reserve required from commercial banks at Bank Indonesia is the ratio of loans they offer to third parties in both rupiah and foreign currency. So, LDR measures the composition of the amount of credit given compared to the number of public funds and capital used. An increase in the LDR value will affect profits to grow up through credit creation. A high LDR indicates that there is an investment from large third parties in the form of credit. Large credit distribution will improve company performance because it shows that the company is better at managing credit and can give investors confidence, thereby directly increasing stock returns (Khaddafi and Syamn, 2011), Kurniadi, 2012); Zulbett, 2011).

Profitability is usable for measuring the success of a company in its performance to generate profits. The profitability variable is proxied using the return on assets (ROA), which is a measure of how much net profit can be obtained from all the assets owned by the company. Increasing ROA means that the company's performance is getting better, and, as a result, stock returns are also growing (McMillan, 2017; Che, 2018; Bystrom, 2018).

From year to year, the development of the loan-to-deposit ratio and credit growth continued to increase, compared to the growth rate of third party funds. To keep third party funds healthy, one way to do is to strengthen the ratio of low-cost funds by improving cash management services. The loan-to-deposit ratio, according to Bank Indonesia circular letter No. 6/23/DPNP dated May 31, 2004, is the ratio of credit extended to third parties (current accounts, savings, certificates of deposit, and deposits). Based on this circular, the credit ratio at commercial banks continues to develop well, because banks can manage credit optimally and adequately so that their performances are immediately more favorable, thus encouraging the increase in the value of profitability obtained from lending activities. The increase in profitability has an impact on the more positive value of stock returns gained by investors. 


\section{Literature Review}

\subsection{Loan-to-deposit Ratio}

The loan-to-deposit ratio (LDR) is a ratio that measures the amount of credit provided by the bank divided by the number of funds collected from the public and the capital used (Kasmir, 2012). Seeing the bank's ability to manage LDR optimally can provide a positive value for company performance. The LDR calculation can be done using the following formula:

Source : Messai and Jouini (2013)

$$
\text { Loan deposit ratio }=\frac{\text { Total loans }}{\text { Total deposit }+ \text { equity }}
$$

\subsection{Profitability}

Profitability is the company's ability to make a profit. It shows the ability of a company to generate profits at a certain level of assets and share capital (Husnan, 2001). Shapiro (1991) also explained that profitability measures management objectives, as shown by the return on assets and owner's equity. The higher the profitability obtained by the bank, the more optimal the company's performance and the higher the return expected by investors. Profitability in the company is measurable using the return on assets (ROA), which is the company's ability to manage its assets optimally for profit. The higher the ROA obtained, the higher the profits and the better the company's position in using assets. ROA can be calculated using the following formula:

Source: Suselo, Djazuli, and Indrawati (2014)

$$
\text { Return on assets }=\frac{\text { Net income after tax }}{\text { Total aset }}
$$

\subsection{Stock Returns}

Stock returns reflect the level of profit obtained by the owner of capital on an investment that has been made, both from short-term and long-term investments that have the main objective of making a profit (Ang, 1997). Stock returns show the change in the value of shares plus the distribution of cash received from them (Asna \& Graha, 2006). Shareholders in their investment can get the returns offered by the shares in the form of capital gains (the difference between the selling value and the purchase value) and dividends. Stock returns are calculated by the following formula:

Note:

$$
\mathrm{Rt}=\frac{\mathrm{Pt}-(\mathrm{Pt}-1)}{\mathrm{Pt}-1}
$$

Rt : Stock returns

$\mathrm{Pt} \quad$ : Current share price

Pt-1 : Previous period share price

Source: Khaddafi \& Syamni (2011)

\section{Research Method}

This research was explanatory research aimed to explain the relationship between variables through hypothesis testing. This research was conducted on the Indonesia Stock Exchange using secondary data in the form of financial reports, annual reports, and annual Indonesian Capital Market Directory (ICMD) in bank companies in the period 2013 to 2018 obtained from the Investment Gallery of Universitas Brawijaya, Malang, Indonesia. The target sample in this study had several requirements, namely: banks having presented their audited financial statements ending on December 31, 2013, until 2018, having positive equity from 2013 to 2018, and having a positive profit from 2013 to 2018. Of the 43 banks listed on the IDX, 20 bank companies met the criteria and requirements as the research sample.

The data used were quantitative, namely research data in the form of numbers and analysis using statistics (Levin \& Rubin, 1998). This study used pooled data for the period 2013 to 2018. According to Ghozali (2011), pooled data are those having a combination of two elements, namely time series and cross-sectional. Pooled data is obtained by combining time-series data, which, in this study, is six years (during the study period 2013 - 2018), and cross-sectional data, namely as many as 20 companies, so that the number of data observed was 120 observations. Figure 1 below shows the relationship between the variables studied: 


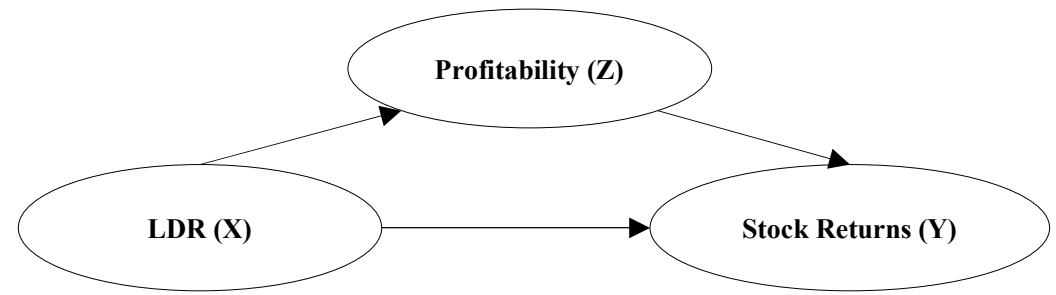

Figure 1. Conceptual Framework.

Based on this conceptual framework, in this study, the following hypotheses will be tested.

H1 : Loan-to-deposit ratio has a significant effect on bank profitability

H2 : Loan-to-deposit ratio has a significant effect on bank stock returns

H3 : Profitability has a significant effect on bank stock returns

H4 : Profitability mediates the effect of the loan-to-deposit ratio on bank profitability

Based on the existing research design, this study used the Partial Least Square (PLS) analytical model because several research hypotheses did not yet have a solid theoretical basis. PLS is a powerful analytical method because it is not based on many assumptions; the data does not have to be normally distributed; the sample size does not have to be large, and; it is able to explain the relationship between latent variables (Ghozali, 2011).

\section{Results and Discussion}

The results of SEM analysis with Smart PLS version 3.0 software are as in table 1 below:

Table 1 . The results of the analysis of the relationship between variables

\begin{tabular}{|l|r|r|r|r|r|r|}
\hline \multicolumn{1}{|c|}{ Variable } & \multicolumn{1}{c|}{$\begin{array}{c}\text { Original } \\
\text { Sample (O) }\end{array}$} & $\begin{array}{c}\text { Sample } \\
\text { Mean (M) }\end{array}$ & $\begin{array}{c}\text { Stand. } \\
\text { Deviation } \\
\text { (SD) }\end{array}$ & $\begin{array}{c}\boldsymbol{t} \text { - } \\
\text { statistics }\end{array}$ & $\begin{array}{c}\boldsymbol{p} \text { - } \\
\text { values }\end{array}$ & Note \\
\hline LDR $\rightarrow$ Profitability & .122 & .128 & .048 & 2.528 & .006 & Significant \\
\hline LDR $\rightarrow$ Stock Returns & .217 & .216 & .098 & 2.208 & .014 & Significant \\
\hline $\begin{array}{l}\text { Profitability } \rightarrow \text { Stock } \\
\text { Returns }\end{array}$ & .407 & .425 & .120 & 3.383 & .000 & Significant \\
\hline $\begin{array}{l}\text { LDR } \rightarrow \text { Profitability } \rightarrow \\
\text { Stock Returns } \\
\text { (Mediation) }\end{array}$ & .050 & .055 & .026 & 1.892 & .030 & Significant \\
\hline
\end{tabular}

\subsection{Effect of the Loan-to-deposit Ratio (LDR) on Profitability}

Based on the results of the analysis presented in Table 1 , the probability value ( $p$-value) is 0.006 , less than 0.05 . Thus, it can be said that the variable loan-to-deposit ratio (LDR) has a significant effect on the profitability of banking companies on the Indonesia Stock Exchange. The results of this analysis indicated that the level of the LDR ratio would cause changes to the profitability obtained by the bank. LDR is the ratio between total credits to third party funds. Bank Indonesia determines that a bank company is said to be healthy if its LDR is less than $90 \%$; if this ratio is too high, which is more than $102.26 \%$, the bank is not healthy (Asna \& Nugraha, 2006).

Indonesian bank regulation Number $15 / 7 / \mathrm{PBI} / 2013$ concerning the loan-to-deposit ratio states that the minimum statutory reserve requirement for commercial banks at Indonesian banks in rupiah and foreign currency is the ratio of credit extended to third parties. Kasmir (2013) stated that LDR is a ratio to determine a bank's ability to repay its obligations to customers who have invested their funds with credits that have been given to debtors. Meanwhile, according to Harmono (2011), LDR can be used as an illustration, to what extent the savings collected can support loans that have been issued. The LDR measures the composition of the amount of credit extended, compared to the number of public funds and capital used. The high LDR can be seen from the increase in credit growth, namely from investment credit, working capital credit, and public consumption credit such as electricity, water, gas, and trade.

Basically, banking activity is to withdraw funds from the public and distribute them in the form of credit. The source of banking income is interest from funds channeled (credit) so that if the proportion of interest income is greater than the interest cost it is liable for, the profit will be greater. Developments in the management of credit growth that are increasingly positive will create better conditions for company performance. Thus, it can be ascertained that there will be an increase in profits obtained by bank companies. The increase in profit earned by the company has a significant direct effect on profitability to increase. The findings in this study were also in line with some of the results of previous studies (Syamni, 2011; Kurniadi, 2012; Zulbetti, 2011), which stated that LDR has a significant effect on profitability. 


\subsection{Effect of the Loan-to-deposit Ratio (LDR) on Stock Returns}

The results of the analysis in Table 1 show that the probability value ( $p$-value) is 0.014 , smaller than 0.05 , indicating that the loan-to-deposit ratio (LDR) variable has a significant effect on stock returns of banking companies in the Indonesia Stock Exchange. The results of this analysis show that the level of the LDR ratio will cause changes in the returns that investors will receive. Banking activity is basically collecting funds from the public and channeling them in the form of credit (Asna \& Nugraha, 2006). The source of banking income is interest income from funds channeled (credit) so that the higher the interest income than the interest cost it is liable for, the higher the profit.

LDR is a measure of liquidity that measures the number of funds placed in the form of credit originating from funds collected by banks, especially public funds, and used capital (Kasmir, 2012). An increase in the loan-todeposit ratio can affect an increase in profits through credit distribution, which continues to increase. Increasing credit distribution to the public can improve the company's performance because, in managing credit optimally and adequately, it can provide confidence to investors so that it directly has a significant effect on stock returns to increase (Khaddafi and Syamni, 2011; Kurniadi, 2012; Zulbetti, 2011).

On the other hand, research conducted by Kuspita (2011), Syauta and Widjaja (2009) stated that the loan-todeposit ratio has no significant effect on stock returns. It shows that banks are less effective in extending credit, due to the increase in bank lending rates, resulting in a decrease in demand for credit from the public and leading the effectiveness of company performance to be less optimal. The decline in company performance causes the profits earned to decline and, also, the profits obtained by banks to be less than optimal, which has a direct impact on the decline in stock returns obtained by investors.

\subsection{Effect of Profitability on Stock Returns}

Hypothesis testing in Table 1 shows that profitability has a significant effect on stock returns $(0.000<0.005)$. That means that the higher the profitability, the higher the company's value, and the company's shares will be in great demand by investors, which can cause the company's stock price to increase. This condition will cause the distribution of returns to shareholders to increase in size, resulting in an increase in stock returns obtained by investors. The results of this study are supported by the results of research by Kabajeh et al. (2012) and Olowoniyi (2012), which found that profitability has a positive effect on stock returns.

The bank's ability to generate profits in its operational activities is the main focus in assessing company performance (Budiharjo, 2018). This is because company profits, apart from being an indicator of the company's ability to fulfill its obligations for its funders, are also an element in the creation of company value that shows the company's prospects. According to Gitman (2003), profitability is the relationship between income and costs generated by using company assets, both currently and in productive activities. Meanwhile, Kasmir (2014) stated that profitability functions to assess a company's ability to seek profit. The profitability variable is proxied using the return on assets, which is the ability of bank management to obtain overall net income (Hendrawan and Lestari, 2016).

The development of ROA in the last few years continued to increase because banks could optimize their assets properly to generate profits by increasing the growth and composition of their earning assets, such as investment in bank funds in the form of loans in the form of rupiah and foreign currency, placement of interbank funds, and securities.

Increasing ROA in increasing profits can improve company performance to be better and directly have a significant effect on stock returns for investors to increase (McMillan, 2017; Che, 2018; Bystrom, 2018). The increase in credit interest greatly affects the decline in lending, leading to a decline in profits earned by bank companies. The decline in company profits resulted in the return on assets in banks to be not optimal so that the company's performance was less than optimal and had a direct effect on the decline in stock returns for investors.

\subsection{Effect of LDR on Stock Returns through the Variable Profitability}

The loan-to-deposit ratio is the number of funds placed in the form of credit that originates from public funds and own capital collected by the bank (Kasmir, 2012). Meanwhile, according to Harmono (2011), LDR is a ratio that describes the extent to which the deposits that have been collected can support loans issued by banks.

In recent years, the development of the loan-to-deposit ratio has continued to increase, which can be seen from the higher the distribution of credit to the public that will encourage an increase in net profit obtained by bank companies. The increase in credit distribution to the public is based on the fact that bank management can work optimally in the use of company assets to generate net income from company activities (Khrawish, 2011).

The increase in net profit in profitability in banking can attract investors to invest in banking companies and have a direct impact on stock prices to rise. Thus, the high return on shares will be received by investors. This statement is in accordance with the results of research, which stated that LDR has a significant effect on stock returns through profitability as a mediating variable (Setiawan \& Triaryati, 2015). 


\section{Conclusion and Recommendation}

The significant effect of the loan-to-deposit ratio on profitability has been proven in this study. Banks can manage loans on target and optimally, leading the loan-to-deposit ratio to increase directly and improving profitability to rise.

The results also show that the loan-to-deposit ratio has a significant effect on stock returns, proving that in their operational activities, banks can manage credit well. The better credit management will have a direct effect on the increase in stock returns.

Profitability is proven to have a significant effect on stock returns. The increasing development of profitability indicates that the company's performance is getting more positive. This condition affects the increase in stock returns for investors.

The results of this study showed that the loan-to-deposit ratio significantly affects stock returns through profitability. The bank managed to manage its credit development well. This creates better performance conditions and has a direct impact on the increase in stock returns obtained by investors.

Investors must pay attention to the performance of the bank company, which provides good development information for owners of capital to invest in banking companies. Companies must pay attention to the loan-todeposit ratio because the higher the credit managed by the company to be distributed to the public, the more likely it is to create the company performance to be optimal. The increase in LDR has a positive impact on the profitability and return of shares obtained by investors.

\section{References}

Ang, R. 1997. Buku Pintar Pasar Modal Indonesia (The Intelligent Guide to Indonesian Capital Market). Jakarta: Mediasoft Indonesia.

Asna and Nugraha, A. 2006. Analisis Pengaruh Rasio Keuangan Terhadap Return Saham Perbankan Yang Terdaftar Di Bursa Efek Jakarta. Modernisasi, 2(3), 192-211.

Bystrom, H. 2018. Stock Return Expectations in The Credit Market. International Review of Financial Analysis, $56,85-92$.

Che. L. 2018. Investor Types and Stock Return Volatility. Journal of Empirical Finance, 47. 139-161.

Dewi, A.R. 2019. Pengaruh LDR, NIM Dan ROA terhadap Return Saham (Studi Kasus pada Bank Umum yang Terdaftar di Bursa Efek Indonesia 2014-2017). Jurnal Manajemen \& Kewirausahaan, 7(1), 69-77.

Ekpu, V. dan Paloni, A. 2016. Business Lending and Bank Profitability in The UK. International Journal of Studies in Economics and Finance, 33 (2), 302-319.

Fahmi, I. 2012. Analisis Kinerja Keuangan, Bandung: Alfabeta.

Gitman, L. J. 2003. "Principles of Manajerial Finance". International Edition. 10th edition. Pearson Education. Boston.

Harmono. 2011. Manajemen Keuangan Berbasis Balanced Scorecard Pendekatan Teori, Kasus, dan Riset Bisnis. Edisi kesatu. Jakarta: Bumi Aksara.

Hendrawan, Y., \& Lestari, H. 2017. Faktor - Faktor Penentu Profitabilitas Bank Umum Yang Terdaftar Di Bursa Efek Indonesia (BEI). Jurnal Manajemen dan Pemasaran Jasa, 9(1), 99-118. doi:http://dx.doi.org/10.25105/jmpj.v9i1.1413.

Husnan, S. 2001. Manajemen Keuangan Teori Dan Penerapan (Keputusan Jangka Pendek). Yogyakarta : BPFE.

Jogiyanto, H. M. 2008. Teori Portofolio dan Analisis Investasi. Edisi keempat. Yogyakarta: BPFE UGM

Kabajeh, Majed Abdel Majid, Said Mukhled Ahmed AL Nu'aimat, dn Firas Naim Damash. 2012. The Relationship Between the ROA, ROE, and ROI Ratios with Jordanian Insurance Public Companies Market Share Price. International Journal of Humanities and Social Science, 2(11) 115-120.

Kasmir. 2009. Analisis Laporan Keuangan. Rajawali Pers, Jakarta.

Kasmir. 2012. Bank dan Lembaga Keuangan Lainnya. Jakarta: PT Raja Grafindo Persada.

Kasmir. 2013. Analisis Laporan Keuangan. Jakarta: PT Raja Grafindo Persada.

Kasmir, 2014. Analisis Laporan Keuangan. Jakarta: PT. Rajagrafindo Persada.

Khaddafi dan Syamni. 2011. Hubungan Rasio Camel Dengan Return Saham Pada Perusahaan Perbankan di Bursa Efek Indonesia. Jurnal Aplikasi Manajemen, 9(3), 1693 - 5241.

Khrawish, H.A. 2011. Determinants of Commercial Banks Performance: Evidence from Jordan. International Research Journal of Finance and Economics, 5(5), 19-45.

Kurniadi dan Mawardi. 2012. Pengaruh CAR, NIM, LDR Terhadap Return Saham Perusahaan Perbankan Indonesia. Accounting Analysis Journal, 1(1), 7-11. https://doi.org/10.15294/aaj.v1i1.335.

Kuspita, M. 2011. Pengaruh CAR, LDR, NPL, BOPO, ROA dan DPS Terhadap Return Saham Pada Perusahaan Perbankan Yang Terdaftar di Bursa Efek Indonesia. Tesis. UPN Yogyakarta.

Levin, R., I. dan Rubin, D., S. 1998. Statistic for management 7th ed. USA.: Prentice-Hall.

Malleret, et al. 2008. Berbisnis Dengan Osama Mengubah Risiko Global Menjadi Peluang Sukses. Jakarta: Serambi Ilmu Semesta. 
Masyhud, A. 2006. Asset Liability Management: Menyiasati Risiko Pasar dan Risiko Operasional. Jakarta: PT Gramedia.

McMillan, D., G. 2017. Predicting firm level stock returns: Implications for asset pricing and economic links. Journal The British Accounting Review, 51, 333-351.

Messai. A., S. dan Jouini. F. 2013. Micro and Macro Determinants of Non Performing Loans. International Journal of Economics and Financial Issue, 3(4), 852-860, 2146-4138.

Munawar, A. H. 2018. Pengaruh Loan to Deposit Ratio dan Debt to Equity Ratio Terhadap Return On Assets Pada PT Bank Mandiri (Persero) TBK. Jurnal Ilmiah Adbis, 2(2), 1-12.

Nguyen, T. N. dan Stewart, C. 2013. Concentration and efficiency in the Vietnamese banking system between 1999 and 2009 a structural model approach. Journal of Financial Regulation and Compliance, 21(3), 268-283.

Olowoniyi dan Ojenike. 2012. Determinants of Stock Return of Nigerian-Listed Firms. Journal of Emerging Trends in Economics and Management Dynamics, 1(11) 389-392.

Prasetyorini, B. F. 2013. Pengaruh Ukuran Perusahaan, Leverage, Price Earning Ratio dan Profitabilitas terhadap Nilai Perusahaan. Jurnal Ilmu Manajemen, 1(1), 183-196..

Setiawan. 2009. Analisis Pengaruh Faktor Makro, Ekonomi, Pangsa Pasar dan Karakteristik Bank Terhadap Profitabilitas Pada Bank. Tesis, Fakultas Ekonomi Universitas Diponegoro.

Setiawan, P.B.R. dan Triaryati, N. 2016. Peran Profitabilitas Dalam Memediasi Pengaruh Leverage Terhadapreturn Saham Pada Perusahaan Food and Beverages, E-Jurnal Manajemen Unud, 5(5), 2972 - 2999.

Shapiro, A. C. 1991. Modern Corporate Finance. Macmillan Publishing Company.

Suselo, D. Djazuli, A. dan Indrawati, N, K. 2014. Pengaruh Variabel Fundamental dan Makro Ekonomi terhadap Harga Saham (Studi pada Perusahaan yang Masuk dalam Indeks LQ45). Jurnal Aplikasi Manajemen, 13(1), $104-116$.

Susilowati, Y. 2011. Reaksi Signal Rasio Profitabilitas dan Rasio Solvabilitas Terhadap Return Saham Perusahaan. Dinamika Keuangan dan Perbankan, 3(1), 17-37.

Syauta, C. R. dan Widjaja, I. 2009. "Analisis Pengaruh Rasio ROA, LDR, NIM dan NPL terhadap Abnormal Return Saham Perbankan di Indonesia Pada Periode Sekitar Pengumuman Subprime Mortgage”. Journal of Applied Finance and Accounting, 1(2), 351-367.

Zulbetti, R. 2011. Pengaruh Rasio-Rasio CAMEL dan Faktor-Faktor Makroekonomi Terhadap Return Saham (Studi Empiris Pada Perusahaan Perbankan Yang Terdaftar di Bursa Efek Indonesia Periode 2000-2010). Banking and Management Review, 1(1), 48-62. 